\title{
Hydrogeochemical modeling based approach for evaluation of groundwater suitability for irrigational use in Korba district, Chhattisgarh, Central India
}

\author{
Soumya S. Singha ${ }^{1} \cdot$ Srinivas Pasupuleti ${ }^{1}$
}

Received: 19 February 2020 / Accepted: 17 August 2020 / Published online: 25 August 2020

(c) Springer Nature Switzerland AG 2020

\begin{abstract}
Systematic assessment of groundwater suitability for irrigation purpose was evaluated in Korba district, Chhattisgarh, Central India. As a part of the assessment, groundwater physico-chemical data of 56 locations were considered. Ascertaining the groundwater suitability and its characteristics, various quality indices and hydrogeochemical studies were performed. Quality results showed that groundwater of the study area was mostly alkaline in nature, where a total of $17 \%$ groundwater samples were found hard to very hard, $9 \%$ were slight to moderate hazard, and $4 \%$ were high saline type. Chemical indices, namely Sodium percentage ( $\mathrm{Na} \%)$, Sodium adsorption ratio (SAR), Residual sodium carbonate (RSC), Permeability Index (PI), Kelly's ratio (KR) and Magnesium adsorption ratio (MAR) were evaluated. According to the computed indices, majority of the samples were found to be suitable for irrigation. Based on USSL plot, around $54 \%$ of samples fell in $C_{1}-S_{1}$ and $C_{2}-S_{1}$ fields, indicating low to medium salinity with a low alkali hazard. Hence, groundwater fell under $\mathrm{C}_{1}-\mathrm{S}_{1}$ and $\mathrm{C}_{2}-\mathrm{S}_{1}$ fields can be used to irrigate all kind of soils with marginal increase of risk level for exchangeable $\mathrm{Na}^{+}$content. Results of hydrogeochemical model suggested that groundwater of the study area were mainly influenced by rock-water interaction phenomena. Groundwater hydrogeochemical facies was characterized through Piper plot and Chadha's diagram, which showed $\mathrm{Ca}-\mathrm{Mg}-\mathrm{HCO}_{3}$ type groundwater as the dominating facies within the study region.
\end{abstract}

Keywords Groundwater · Irrigation groundwater suitability · Hydrogeochemistry · Rock-water interaction · Korba

\section{Introduction}

Globally, groundwater is a major source of water that is used for agriculture, domestic, and drinking purposes. Often its quality is ignored, especially for irrigation use. However, where groundwater source and irrigation system are essential to agricultural practices, quality is important in terms of leaching fractions, irrigation management, and also for water treatment in order to achieve maximum crop productivity [1]. Extensive application of insecticides, pesticides and synthetic fertilizers for agricultural production in recent years have raised serious concerns regarding degradation of groundwater quality [2]. While a rapidly growing population and increasing industrial activities are contributing to anthropogenic pollution in both surface and sub-surface water,fluoride, arsenic, highly dissolved solids, and iron concentration in groundwater are causing geogenic pollution [3]. Agriculture is a major sector in India and contributes approximately $14 \%$ of the Gross Domestic Product (GDP) [4]. This underlines the need for good quality of irrigation groundwater.

The quality of irrigation water is defined in terms of TDS, major cations $\left(\mathrm{Ca}^{2+}, \mathrm{Mg}^{2+}, \mathrm{Na}^{+}, \mathrm{K}^{+}\right)$, and anions $\left(\mathrm{HCO}_{3}{ }^{-}\right.$and $\left.\mathrm{CO}_{3}^{2-}\right)$; an excess concentration of these in groundwater will lead to sodicity, salinity, and permeability problems in the soil, thereby hampering plant growth and crop yield [4].

Srinivas Pasupuleti, srinivas@iitism.ac.in; Soumya S. Singha, soumya.2014dr1085@cve.iitism.ac.in | Department of Civil Engineering, Indian Institute of Technology (Indian School of Mines), Dhanbad, Jharkhand, India. 
Deterioration in the physical properties of soil in the long run hinges on the quantum of total dissolved salts, sodium carbonate, and sodium bicarbonate concentrations in irrigated water [5]. Globally, the most widespread problems associated with poor water quality are increased salinity, reduced infiltration rate, and specific ions $\left(\mathrm{Na}^{+}, \mathrm{Cl}\right)$ toxicity [6]. However, these problems vary depending on the type of crop grown, climate, soil type, drainage, irrigation method, etc. Good quality water is very essential to sustain crop production and to prevent damage to sensitive crops from salts, pesticides, and trace metals [7]. Moreover, low sodium irrigation water is very essential to sustain soil structure stability [8]. Therefore, it is important to evaluate the main variables while classifying irrigation water quality.

A hydrogeochemical study gives a clearer understanding of plausible changes in water quality as development takes place. The geochemistry of groundwater can demonstrate its suitability for irrigation usage [9]. Water is an excellent solvent, so it is essential to know the geochemistry of dissolved constituents and methods of reporting data. Chemometric techniques such as correlation analysis, graphical analysis, and factor analysis play a major role in the elaborate study of groundwater geochemistry and the interdependence of ions.

The residents at Korba district depends on groundwater resources for drinking, domestic, industrial and agricultural purpose [10]. Though the study area is known for extensive coal mining activities, still agricultural practices are an important economic activity. This study aims to assess the quality and suitability of groundwater for irrigation in the study area. Therefore, this study is undertaken as an initial attempt to illustrate the level and nature of groundwater pollution as it is also associated with mining activities. Till date no such systematic analysis regarding irrigation suitability has been carried out in the entire Korba district, Central India as per the knowledge of authors.

This study focuses on assessing the quality of groundwater for its suitability for irrigation in Korba district, using a multiparametric hydrochemical approach. The sub-objectives of this study are: (1) to understand the hydrogeochemical characteristics of groundwater based on absolute amount of ions; (2) to ascertain the principle variables (indices) based on interactions among ions, for the classification of irrigation water suitability; and (3) to identify the dominant hydrogeochemical processes controlling groundwater geochemistry.

The remaining part of the paper is organized as follows. In Sect. 2, the detail description of the study area is discussed. Section 3 includes the data collection of groundwater physico-chemical parameters, computation of groundwater quality indices and the groundwater hydrogeochemical analysis. Section 4 includes the result of the current research work along with discussions. Finally in Sect. 5 the overall research work is conluded with suggestive future works.

\section{Study area}

The Korba district is the industrial hub of Chhattisgarh state and situated between $22^{\circ} 01^{\prime} 50^{\prime \prime}$ and $23^{\circ} 01^{\prime} 20^{\prime \prime} \mathrm{N}$ latitude and between $82^{\circ} 07^{\prime} 20^{\prime \prime}$ and $83^{\circ} 07^{\prime} 50^{\prime \prime} \mathrm{E}$ longitude (Fig. 1). The total geographical area of the study area is 7145.44 sq.km and comprises blocks, namely, Podi upraroa, Korba, Kartala, Katghora and Pali. The study area is blessed with abundant minerals like coal, bauxite, fire clay, building stone, and limestone. Some of the major coal mines such as Gevra (one of the biggest coal mines of Asia), Kusmunda and Dipka, all located in Korba Coalfields (KCF) reported that the Korba district is categorized into three major geological groups viz., Chotanagpur Gneissic Complex (CGC), Chhattisgarh Supergroup (CSG) and Gondwana Supergroup [11]. However, CGC and gondwanas encompass over $90 \%$ of the study region. Talchir, Karaharbhari, Barakar and Kamthi Formations belong to Gondwana Supergroup. The huge tract between Korba and Hasdeo-Anand Coalfield is occupied by Talchir group. Karaharbhari Formation comprises of sub greywacke and pebbly sandstone is marked as a narrow linear patch in the extreme north eastern portion, while the Barakar Formation comprising of feldspathic and ferruginous type of sandstone extends over the major portion of the KorbaGondwana basin. The Kamthi Formation comprising of coarse type ferruginous sandstone with shale and coal seams forms prominent ridges in the eastern part of the Korba district. Geology map of the study area is shown in Fig. 2. Around $54 \%$ (3882.79 sq. km) of the total area is covered by forests, 2595.86 sq.km (36\% approx.) is covered by agricultural lands while rest 666.79 sq.km is covered by Waste/barren land, mining area, water body and builtup area [12]. Kharif is the primary cropping season in the study area and Paddy is the main crop followed by wheat, maize and jawar. Pulses, oilseeds, sugarcane, etc. are also grown in the region. Paddy is sown in nearly $83 \%$ of the net sown area. The principal soils of the district include ultisols, inceptisols and alfisols.

\section{Methodology}

\subsection{Physico-chemical dataset}

The pre-monsoon (May) groundwater physico-chemical data for 56 locations were collected from the Central Ground Water Year Book, 2016-2017 to analyze their 

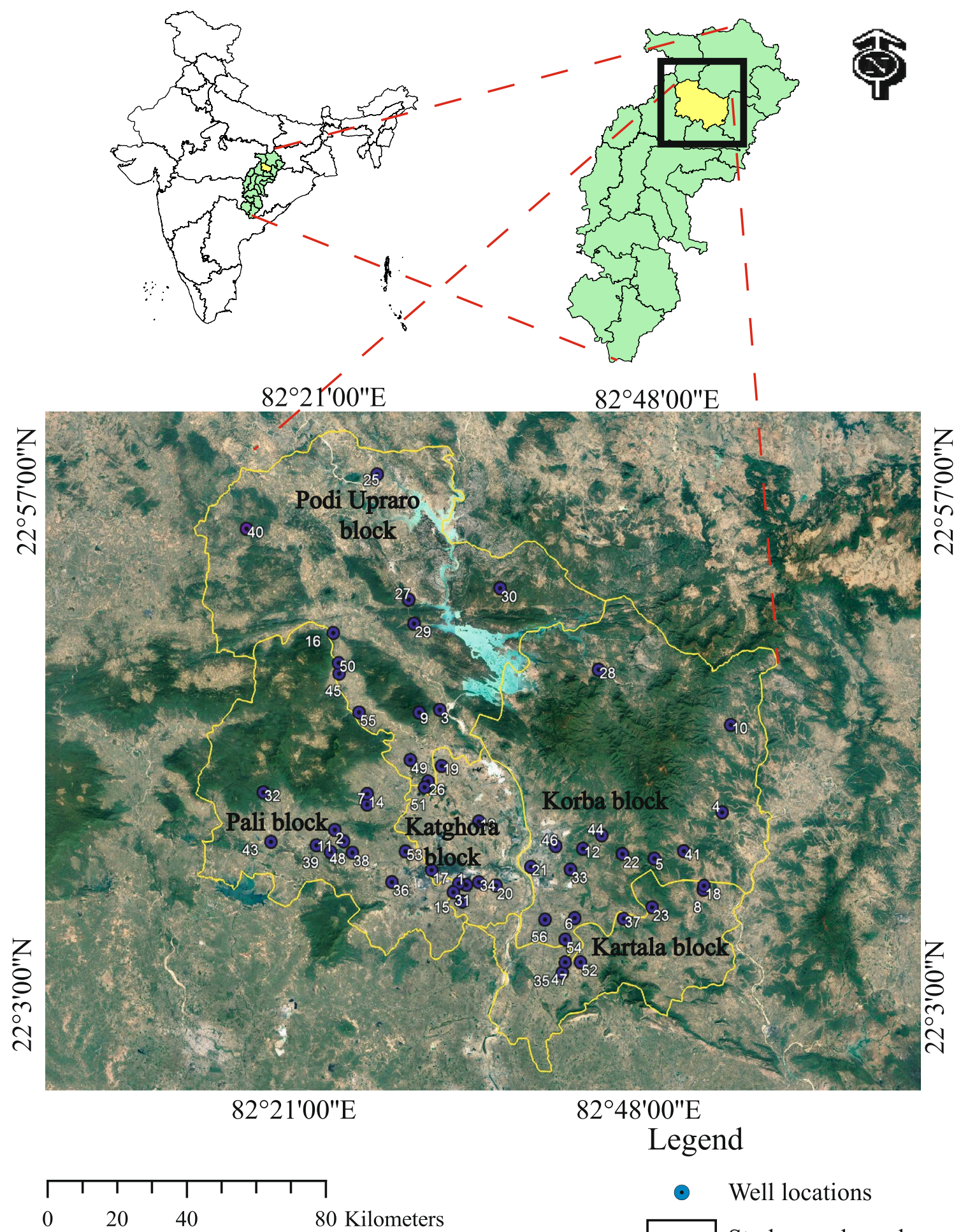

- Well locations

Study area boundary

Fig. 1 Location map of the study area

suitability for irrigation purposes. Seventeen physicochemical parameters were selected namely, pH, EC (Electrical Conductivity), TDS (Total dissolved solids), TA (Total alkalinity), $\mathrm{TH}$ (Total hardness), $\mathrm{Ca}^{2+}, \mathrm{Mg}^{2+}, \mathrm{Na}^{+}, \mathrm{K}^{+}, \mathrm{Fe}^{2+}$,
$\mathrm{HCO}_{3}^{-}, \mathrm{CO}_{3}^{2-}, \mathrm{SO}_{4}^{2-}, \mathrm{Cl}^{-}, \mathrm{F}^{-}, \mathrm{SiO}_{2}$ and $\mathrm{PO}_{4}^{3-}$. All the parameters were expressed in $\mathrm{mg} / \mathrm{L}$ except $\mathrm{pH}$ (unitless) and $\mathrm{EC}(\mu \mathrm{S} /$ $\mathrm{cm}$ ). Various chemical/quality indices were computed by considering the concentrations of groundwater major 
Fig. 2 Geology map of the study area

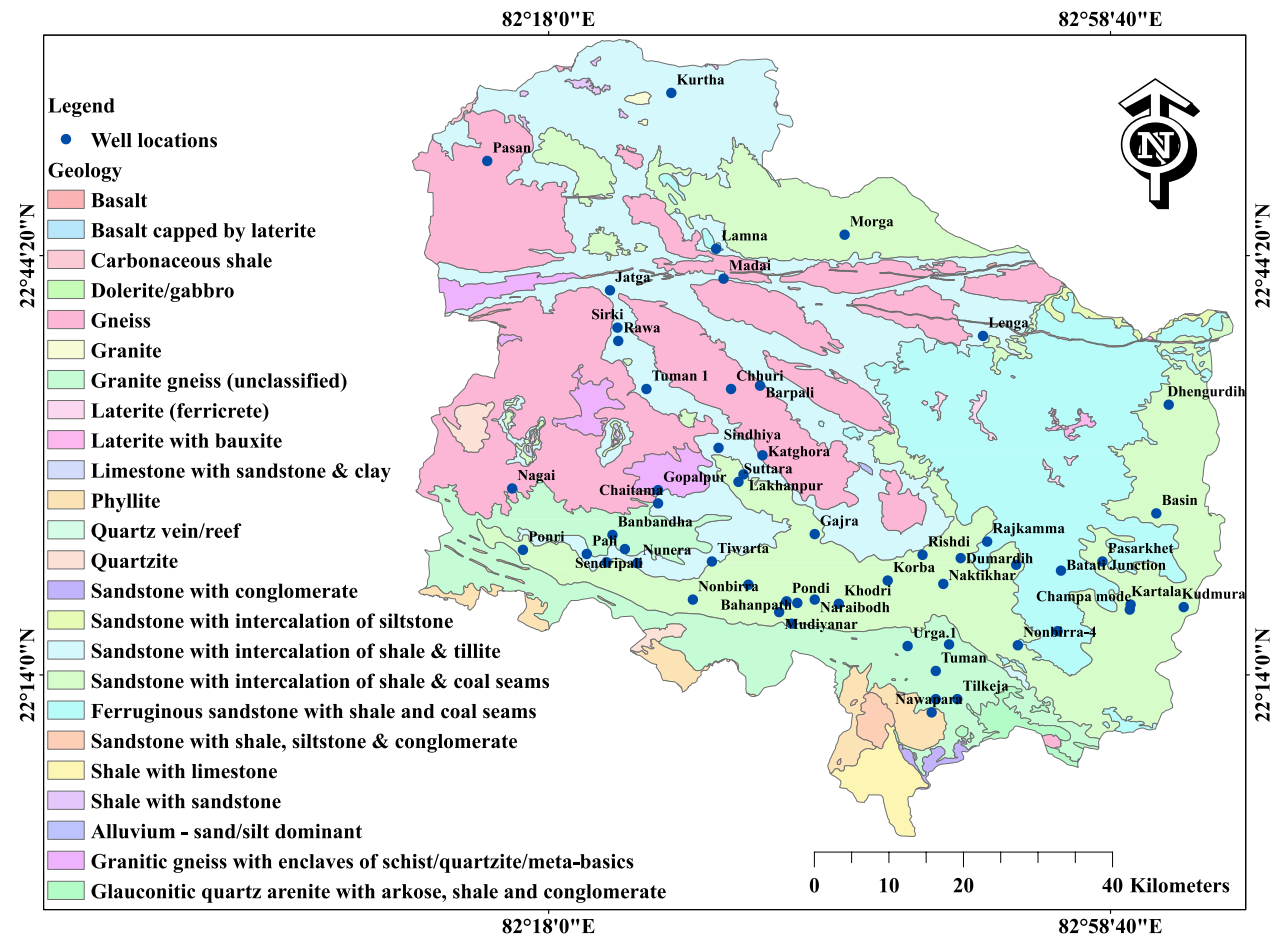

cations and anions and by using the standard formulae. Various irrigation water quality indices including Sodium percentage (Na\%), Sodium adsorption ratio (SAR), Residual sodium carbonate (RSC), Permeability index (PI), Kelly's ratio (KR), and Magnesium adsorption ratio (MAR) were determined. All indices were determined by converting the respective ions from $\mathrm{mg} / \mathrm{L}$ to $\mathrm{meq} / \mathrm{L}$.

\subsection{Evaluation of irrigation quality indices}

\subsubsection{Na\%}

Sodium percentage was used to assess sodium hazard in groundwater with respect to water quality for irrigation usage. Doneen [13] and Wilcox [14] define sodium soluble percentage as:

$\mathrm{Na}(\%)=\frac{\left[\mathrm{Na}^{+}\right]+\left[\mathrm{K}^{+}\right]}{\left[\mathrm{Na}^{+}\right]+\left[\mathrm{K}^{+}\right]+\left[\mathrm{Ca}^{2+}\right]+\left[\mathrm{Mg}^{2+}\right]} * 100$

Water with less than $20 \% \mathrm{Na}$ was classified as excellent water for irrigation purpose, as suggested by [14].

\subsubsection{SAR}

SAR is one of the most important indices to assess sodium/ alkalinity in groundwater associated with the presence of high $\mathrm{Na}^{+}$and low $\mathrm{Ca}^{2+}$ and $\mathrm{Mg}^{2+}$ concentrations. Hence, higher $\mathrm{Na}^{+}$content signifies higher sodic or alkali hazard in groundwater and conversely, predominance of cations ( $\mathrm{Ca}^{2+}$ and $\mathrm{Mg}^{2+}$ ) in groundwater means lesser alkali hazard. Richards [5] defines SAR as:

$S A R=\frac{\left[\mathrm{Na}^{+}\right]}{\sqrt{\frac{1}{2}\left(\left[\mathrm{Ca}^{2+}\right]+\left[\mathrm{Mg}^{2+}\right]\right)}}$

Water with a SAR value of $<10$ was categorized as excellent water for irrigation use, as proposed by [5]. Lower the ionic strength of the solution, higher is the the sodium hazard for a given SAR.

\subsubsection{RSC}

The RSC was used to evaluate alkalinity hazards associated with high $\mathrm{HCO}_{3}{ }^{-}$and $\mathrm{CO}_{3}^{2-}$ ions in comparison to $\mathrm{Ca}^{2+}$ and $\mathrm{Mg}^{2+}$ ions in groundwater. Eaton [15] define RSC as:

$\operatorname{RSC}(\mathrm{meq} / \mathrm{L})=\left(\left[\mathrm{HCO}_{3}^{-}\right]+\left[\mathrm{CO}_{3}^{2-}\right]\right)+\left(\left[\mathrm{Ca}^{2+}\right]+\left[\mathrm{Mg}^{2+}\right]\right)$

In accordance with the computed indices, RSC values were classified into three subclasses: $<1.25 \mathrm{meq} / \mathrm{L}$ in groundwater was considered safe/suitable for irrigation whereas values between $1.25 \mathrm{meq} / \mathrm{L}$ and $2.5 \mathrm{meq} / \mathrm{L}$ denote marginal safety, and $>2.5 \mathrm{meq} / \mathrm{L}$ denotes non-suitability for irrigation use (Table 2). 


\subsubsection{PI}

Doneen [13] proposed the classification of irrigation water based on permeability index. PI values were evaluated considering $\mathrm{Ca}^{2+}, \mathrm{Mg}^{2+}, \mathrm{Na}^{+}$, and $\mathrm{HCO}_{3}{ }^{-}$ions, as shown in Eq. 4:

$P I(\%)=\frac{\left(\left[\mathrm{Na}^{+}\right]+\left[\sqrt{\mathrm{HCO}_{3}^{-}}\right]\right)}{\left(\left[\mathrm{Ca}^{2+}\right]+\left[\mathrm{Mg}^{2+}\right]+\left[\mathrm{Na}^{+}\right]\right)} * 100$

Accordingly, PI was classified into three subclasses: Class I (PI > 75\%), Class II (PI between 25 and 75\%), and Class III ( $\mathrm{PI}<25 \%)$. Class I and II categories represent water good for irrigation while Class III is considered unsuitable for irrigation.

\subsubsection{KR}

Kelly's ratio is also an important criterion for evaluating suitability of groundwater quality for irrigation purpose. Kelly [16] defines Kelly's ratio as (Eq. 5):

$K R=\frac{\left[\mathrm{Na}^{+}\right]}{\left[\mathrm{Ca}^{2+}\right]+\left[\mathrm{Mg}^{2+}\right]}$

Accordingly, $\mathrm{KR}<1$ indicates good quality water and of $>1$ indicates water unsuitable for irrigation.

\subsubsection{MAR}

MAR was used to assess $\mathrm{Mg}^{2+}$ hazards in water. Paliwal [17] and Rao et al. [18] define MAR as (Eq. 6):

$\operatorname{MAR}(\%)=\frac{\left[\mathrm{Mg}^{2+}\right]}{\left[\mathrm{Ca}^{2+}\right]+\left[\mathrm{Mg}^{2+}\right]} * 100$

If MAR in groundwater exceeds $50 \%$, the water quality was considered unfit for irrigation and if it was less than $50 \%$, it was good for irrigation.

\subsection{Hydrogeochemical analysis}

To understand groundwater geochemistry, the following approaches were considered:

\subsubsection{Gibbs plot}

The plotting of values of specific water quality parameters over Gibbs' diagram [19] provides clarity on which particular factor such as rock-water interaction, evaporation, or precipitation plays a dominant role in controlling the hydrogeochemistry of an area. In the present study Gibbs' diagrams for cations and anions were plotted using the available groundwater chemicals.

\subsubsection{Piper and Chadha's plot}

The overall characterization of hydrogeochemical data is possible by knowing the composition of water and understanding its hydrogeochemical evolution and the grouping of same composition of major dissolved ions that can be graphically depicted through Piper trilinear diagram and Chadha's plot.

Piper trilinear diagram was proposed by [20] to show major cationic and anionic composition of groundwater samples and to assess the hydrogeochemical evolution of groundwater. The Piper plot comprises of three (two triangular and one central diamond-shaped) fields, each reflecting the respective dominant water types. Two triangular fields were plotted separately, one field represented percentage meq/L values of major cations $\left(\mathrm{Ca}^{2+}, \mathrm{Mg}^{2+}\right.$, $\mathrm{Na}^{+}$, and $\mathrm{K}^{+}$) and the other showed percentage meq/ $\mathrm{L}$ values of major anions $\left(\mathrm{HCO}_{3}{ }^{-}, \mathrm{CO}_{3}^{2-}, \mathrm{Cl}^{-}\right.$, and $\left.\mathrm{SO}_{4}^{2-}\right)$, which were projected on the central diamond-shaped plot to identify overall types or characteristics of groundwater chemistry. The central plot between the two triangles represented the groundwater composition of an area with respect to both cations and anions.

Chadha's plot [21] is an expanded version of the Piper plot, which was constructed by plotting the difference between alkaline earths $\left(\mathrm{Ca}^{2+}\right.$ and $\left.\mathrm{Mg}^{2+}\right)$ and alkalis $\left(\mathrm{Na}^{+}\right.$and $\left.\mathrm{K}^{+}\right)$in meq/L on the abscissa and the difference between weak acids $\left(\mathrm{HCO}_{3}{ }^{-}, \mathrm{CO}_{3}^{2-}\right)$ and strong acids $\left(\mathrm{Cl}^{-}\right.$and $\mathrm{SO}_{4}^{2-}$ ) on the ordinate.

\subsubsection{Chloro alkaline indices (CAI)}

Groundwater composition mainly relies on the ion exchange process [22]. Ion exchange between groundwater and its surrounding host rock can be computed by CAl, as suggested by [23]. Evaluation of base-exchange through CAl was computed using the following equation:

$C A I=\frac{\left[\mathrm{Cl}^{-}\right]-\left(\left[\mathrm{Na}^{+}\right]+\left[\mathrm{K}^{+}\right]\right)}{\left[\mathrm{Cl}^{-}\right]}$

The negative value of $\mathrm{CAl}$ implies the exchange of $\mathrm{Na}^{+}$ and $\mathrm{K}^{+}$ions with $\mathrm{Ca}^{2+}$ and $\mathrm{Mg}^{2+}$ of the surrounding host rock material, indicative of cation-anion exchange reaction [24], while the positive value of CAI represents baseexchange reaction among groundwater and the aquifer materials. 


\section{Results and discussion}

\subsection{Groundwater chemistry based on the absolute amount of ions}

The various physico-chemical parameters and irrigation indices with their minimum, maximum, mean concentration, standard deviation (SD), skewness and kurtosis are presented in Table 1. The classification of groundwater samples indicated their suitability for irrigation based on the different quality constituents (Table 2).

The $\mathrm{pH}$ value of the 56 groundwater samples varied between 7.51 and 8.40 (mean value $=8.06$ and $S D=0.21$ ). The $\mathrm{pH}$ results suggested the alkaline nature of the groundwater in the study area. All the samples were found to be within permissible limits i.e., 6-8.5 $[25,26]$ and can be used for irrigation.

Water salinity, measured through EC, was considered as an important measure of irrigation water quality as it affects the productivity of crops. Higher EC concentration in water leads to the formation of saline soil [2]. The higher the EC concentration, the higher is the salt concentration and lesser will be the water available to plants [27]. The groundwater $\mathrm{EC}$ value (at $25^{\circ} \mathrm{C}$ ) in the study area ranged from 80 to $1697 \mu \mathrm{S} / \mathrm{cm}$ (mean value $=322.70 \mu \mathrm{S} /$ $\mathrm{cm}$ and $\mathrm{SD}=266.81 \mu \mathrm{S} / \mathrm{cm}$ ) (Table 1). Based on groundwater EC values, irrigation water was categorized into four subclasses [5] of low salinity: 0-250 $\mu \mathrm{S} / \mathrm{cm}$, moderate salinity: $250-750 \mu \mathrm{S} / \mathrm{cm}$, high salinity: $750-2250 \mu \mathrm{S} /$ $\mathrm{cm}$, and very high salinity: $>2250 \mu \mathrm{S} / \mathrm{cm}$. Result showed that approximately $56 \%$ of the wells in the study area had low saline water, $43 \%$ moderate saline water, and only $1 \%$ (one well) had high saline water (Table 2). As per [28], the EC values showed that majority of the samples $(98.21 \%)$ were categorized as excellent to good (Table 2 ). Since EC is also an indicator of total dissolved salts in water, TDS concentration was also investigated to ascertain salinity hazard.

The TDS value of the groundwater samples varied from 56 to $1187.90 \mathrm{mg} / \mathrm{L}$ (mean value $=225.89 \mathrm{mg} / \mathrm{L}$ and $\mathrm{SD}=186.77 \mathrm{mg} / \mathrm{L}$ ). Based on the classification of TDS as suggested by [29], most of the sampling locations were found suitable for irrigation. A total of $91 \%$ of the samples were suitable for irrigation (wells with TDS $<450 \mathrm{mg} / \mathrm{L}$ ) and $9 \%$ showed slight to moderate hazard (TDS between 450 and $2000 \mathrm{mg} / \mathrm{L}$ ) (Table 2). Therefore, it can be inferred that the groundwater in the study area has low to moderate salinity.
Table 1 Values of various physico-chemical parameters and irrigation water quality indices

\begin{tabular}{|c|c|c|c|c|c|c|}
\hline $\begin{array}{l}\text { Parameters and } \\
\text { irrigation indices }\end{array}$ & Minimum & Maximum & Mean & SD & Skewness & Kurtosis \\
\hline $\mathrm{pH}$ & 7.51 & 8.40 & 8.06 & 0.21 & -1.14 & 0.55 \\
\hline $\mathrm{EC}(\mu \mathrm{S} / \mathrm{cm})$ & 80 & 1697 & 322.70 & 266.81 & 2.86 & 11.99 \\
\hline TDS (mg/L) & 56 & 1187.90 & 225.89 & 186.77 & 2.86 & 11.99 \\
\hline TA (mg/L) & 10 & 220 & 81.52 & 54.51 & 0.68 & -0.59 \\
\hline TH (mg/L) & 15 & 700 & 107.59 & 103.50 & 3.73 & 19.16 \\
\hline $\mathrm{Ca}^{2+}(\mathrm{mg} / \mathrm{L})$ & 4 & 142 & 26.54 & 22.46 & 2.88 & 12.06 \\
\hline $\mathrm{Mg}^{2+}(\mathrm{mg} / \mathrm{L})$ & 1.20 & 82.80 & 9.90 & 12.24 & 4.16 & 22.71 \\
\hline $\mathrm{Na}^{+}(\mathrm{mg} / \mathrm{L})$ & 2.90 & 69.50 & 20.99 & 18.07 & 1.12 & 0.42 \\
\hline $\mathrm{K}^{+}(\mathrm{mg} / \mathrm{L})$ & 0.80 & 26.50 & 6.02 & 4.74 & 1.93 & 6.16 \\
\hline $\mathrm{Fe}^{2+}(\mathrm{mg} / \mathrm{L})$ & 0 & 8.89 & 0.95 & 1.97 & 2.92 & 8.36 \\
\hline $\mathrm{HCO}_{3}^{-}(\mathrm{mg} / \mathrm{L})$ & 12 & 268 & 99.11 & 66.30 & 0.67 & -0.59 \\
\hline $\mathrm{CO}_{3}^{2-}(\mathrm{mg} / \mathrm{L})$ & 0 & 6 & 0.21 & 1.12 & 5.14 & 25.35 \\
\hline $\mathrm{Cl}^{-}(\mathrm{mg} / \mathrm{L})$ & 7.10 & 223.70 & 36.35 & 36.78 & 2.82 & 11.42 \\
\hline $\mathrm{SO}_{4}^{2-}(\mathrm{mg} / \mathrm{L})$ & 0.80 & 104.60 & 14.78 & 18.90 & 2.59 & 8.99 \\
\hline $\mathrm{F}^{-}(\mathrm{mg} / \mathrm{L})$ & 0 & 2.10 & 0.24 & 0.44 & 2.60 & 6.72 \\
\hline $\mathrm{SiO}_{2}(\mathrm{mg} / \mathrm{L})$ & 3.30 & 118.7 & 33.61 & 26.80 & 1.14 & 1.08 \\
\hline $\mathrm{PO}_{4}^{3-}(\mathrm{mg} / \mathrm{L})$ & 0 & 2.41 & 0.36 & 0.46 & 2.13 & 6.11 \\
\hline $\mathrm{Na}(\%)$ & 13.82 & 74.69 & 34.65 & 12.31 & 0.78 & 1.08 \\
\hline SAR & 0.17 & 2.46 & 0.88 & 0.61 & 0.95 & 0.16 \\
\hline $\mathrm{RSC}(\mathrm{meq} / \mathrm{L})$ & -10.29 & 0.81 & -0.51 & 1.53 & -5.02 & 31.14 \\
\hline PI (\%) & 27.60 & 129.24 & 81.50 & 19.84 & -0.27 & 0.29 \\
\hline KR & 0.10 & 2.77 & 0.48 & 0.43 & 3.20 & 14.49 \\
\hline MAR (\%) & 9.90 & 62.24 & 35.92 & 12.11 & -0.01 & -0.47 \\
\hline
\end{tabular}


Table 2 Classification of samples showing their suitability for irrigation based on different groundwater quality constituents

\begin{tabular}{|c|c|c|c|c|}
\hline Parameters and lindices & Range & $\begin{array}{l}\text { Category of irriga- } \\
\text { tion water quality }\end{array}$ & $\begin{array}{l}\text { Number of } \\
\text { samples }\end{array}$ & Description \\
\hline \multirow[t]{3}{*}{ TDS (mg/L) } & $<450$ & Excellent & 51 & Best for irrigation \\
\hline & $450-2000$ & Moderate & 05 & Slight to moderate \\
\hline & $>2000$ & Hazard & 00 & Unsuitable for irrigation \\
\hline \multirow[t]{4}{*}{$\mathrm{EC}(\mu \mathrm{S} / \mathrm{cm})$} & $<250$ & Excellent & 29 & Low salinity hazard \\
\hline & $250-750$ & Good & 26 & Moderate salinity hazard \\
\hline & $750-2250$ & Permissible & 01 & High salinity hazard \\
\hline & $>2250$ & Doubtful & 00 & Very high salinity hazard \\
\hline \multirow[t]{4}{*}{$\mathrm{TH}(\mathrm{mg} / \mathrm{L})$} & $<75$ & Soft & 29 & Suitable \\
\hline & $75-150$ & Moderately hard & 17 & Marginally suitable \\
\hline & $150-300$ & Hard & 09 & Doubtful \\
\hline & $>300$ & Very hard & 01 & Unsuitable \\
\hline \multirow[t]{4}{*}{$\mathrm{Na} \%$} & $0-20$ & Excellent & 06 & Best suited for irrigation \\
\hline & $20-40$ & Good & 34 & Suitable \\
\hline & $40-60$ & Permissible & 15 & Acceptable \\
\hline & $60-80$ & Doubtful & 01 & May be used for irrigation \\
\hline \multirow[t]{4}{*}{ SAR } & $0-10$ & Excellent & 56 & $\begin{array}{l}\text { Suitable in all types of soils and for crops, except for crops } \\
\text { sensitive to } \mathrm{Na}^{+}\end{array}$ \\
\hline & $10-18$ & Good & 00 & Suitable for coarse textured or organic soil with permeability \\
\hline & $18-26$ & Fair & 00 & Harmful for almost all soils \\
\hline & $>26$ & Poor & 00 & Unsuitable for irrigation \\
\hline \multirow[t]{3}{*}{ RSC (meq/L) } & $<1.25$ & Good & 56 & Safe for irrigation \\
\hline & $1.25-2.5$ & Medium & 00 & Marginally suitable for irrigation \\
\hline & $>2.5$ & Bad & 00 & Unsuitable for irrigation \\
\hline \multirow[t]{3}{*}{$\mathrm{PI}(\%)$} & $>75$ & Class I & 37 & Excellent quality for irrigation \\
\hline & $25-75$ & Class II & 19 & Good quality for irrigation \\
\hline & $<25$ & Class III & 00 & Unsuitable for irrigation \\
\hline \multirow[t]{2}{*}{ KR } & $<1$ & Safe & 51 & Suitable for irrigation \\
\hline & $>1$ & Unsafe & 05 & Unsuitable for irrigation \\
\hline \multirow[t]{2}{*}{ MAR (\%) } & $<50$ & Safe & 51 & Suitable for irrigation \\
\hline & $>50$ & Unsafe & 05 & Unsuitable for irrigation \\
\hline
\end{tabular}

Total alkalinity in groundwater signifies the presence of natural salts in the sub-surface water. The permissible limit of TA for irrigation water is below $30 \mathrm{mg} / \mathrm{L}$. The TA in the study region varied from $10 \mathrm{mg} / \mathrm{L}$ to $220 \mathrm{mg} / \mathrm{L}$ (mean value $=81.52 \mathrm{mg} / \mathrm{L}$ and SD $=54.51 \mathrm{mg} / \mathrm{L})($ Table 1$)$.

Total hardness in an area signifies hard water due to the high concentration of $\mathrm{Ca}^{2+}$ and $\mathrm{Mg}^{2+}$ ions and sometimes dissolved compounds such as $\mathrm{Fe}^{2+}$. When $\mathrm{Ca}^{2+}$ and $\mathrm{Mg}^{2+}$ ions react with $\mathrm{HCO}_{3}{ }^{-}$or $\mathrm{Cl}^{-}$or $\mathrm{SO}_{4}^{2-}$ ions, they form insoluble calcium and magnesium carbonate $\left(\mathrm{CaCO}_{3}\right.$ and $\left.\mathrm{MgCO}_{3}\right)$ salts, or chloride $\left(\mathrm{CaCl}_{2}\right.$ and $\left.\mathrm{MgCl}_{2}\right)$ salts or sulphates $\left(\mathrm{CaSO}_{4}\right.$ and $\left.\mathrm{MgSO}_{4}\right)$. $\mathrm{TH}$ in the study area ranged from 15 to $700 \mathrm{mg} / \mathrm{L}$ (mean value $=107.59 \mathrm{mg} / \mathrm{L}$ and $\mathrm{SD}=103.50 \mathrm{mg} / \mathrm{L}$ ). Based on [26] and [30], it was found that $52 \%$ of the wells in the study area have soft water, whereas $31 \%$ of them have moderately hard water, and around $17 \%$ have hard to very hard water (Table 2 ). Van der
Aa [31] reported that hard water greater than $200 \mathrm{mg} / \mathrm{L}$ leads to scaling deposits in piped systems. As groundwater in he study area was predominantly soft to moderately hard (around 83\%), it is suitable for irrigation purposes.

The cations in groundwater samples analyzed in the study area were $\mathrm{Ca}^{2+}, \mathrm{Mg}^{2+}, \mathrm{Na}^{+}, \mathrm{K}^{+}$, and $\mathrm{Fe}^{2+}$. The two dominant soluble cations in the study region are $\mathrm{Ca}^{2+}$ and $\mathrm{Mg}^{2+}$ with concentration values ranging from $4 \mathrm{mg} / \mathrm{L}$ to $142 \mathrm{mg} / \mathrm{L}$ (mean value $=26.54 \mathrm{mg} / \mathrm{L}$ and $\mathrm{SD}=22.46 \mathrm{mg} / \mathrm{L}$ ) and $1.20 \mathrm{mg} / \mathrm{L}$ to $82.80 \mathrm{mg} / \mathrm{L}$ (mean value $=9.90 \mathrm{mg} / \mathrm{L}$ and $\mathrm{SD}=12.24 \mathrm{mg} / \mathrm{L}$ ), respectively. The third and fourth dominant soluble cations are $\mathrm{Na}^{+}$and $\mathrm{K}^{+}$, their values varied from $2.90 \mathrm{mg} / \mathrm{L}$ to $69.50 \mathrm{mg} / \mathrm{L}$ (mean value $=20.99 \mathrm{mg} / \mathrm{L}$ and $\mathrm{SD}=18.07 \mathrm{mg} / \mathrm{L}$ ) and $0.80 \mathrm{mg} / \mathrm{L}$ to $26.50 \mathrm{mg} / \mathrm{L}$ (mean value $=6.02 \mathrm{mg} / \mathrm{L}$ and $\mathrm{SD}=4.74 \mathrm{mg} / \mathrm{L}$ ), respectively. The $\mathrm{Fe}^{2+}$ concentration in the study area ranged from $0 \mathrm{mg} / \mathrm{L}$ to $8.89 \mathrm{mg} / \mathrm{L}$ (mean value $=0.95 \mathrm{mg} / \mathrm{L}$ and $\mathrm{SD}=1.97 \mathrm{mg} / \mathrm{L}$ ). 
Sharifi and Safari [32], Nagaraju et al. [33] reported permissible limits for irrigation water of $\mathrm{Ca}^{2+}$ as $80 \mathrm{mg} / \mathrm{L}, 35 \mathrm{mg} / \mathrm{L}$ for $\mathrm{Mg}^{2+}, 200 \mathrm{mg} / \mathrm{L}$ for $\mathrm{Na}^{+}, 30 \mathrm{mg} / \mathrm{L}$ for $\mathrm{K}^{+}$and $5 \mathrm{mg} / \mathrm{L}$ for $\mathrm{Fe}^{2+}$. According to the limits, all the groundwater samples were suitable for irrigation use except one sampling location with respect to $\mathrm{Ca}^{2+}$ and $\mathrm{Mg}^{2+}$ concentrations and three sampling locations with respect to $\mathrm{Fe}^{2+}$ concentration, which had water unsuitable for irrigation.

Similarly, $\mathrm{HCO}_{3}{ }^{-}, \mathrm{CO}_{3}^{2-}, \mathrm{SO}_{4}^{2-}$, and $\mathrm{Cl}^{-}$were the major groundwater anions in the study area. The concentration of $\mathrm{HCO}_{3}{ }^{-}$varied from $12 \mathrm{mg} / \mathrm{L}$ to $268 \mathrm{mg} / \mathrm{L}$ (mean value $=99.11 \mathrm{mg} / \mathrm{L}$ and $\mathrm{SD}=66.30 \mathrm{mg} / \mathrm{L}$ ), while $\mathrm{CO}_{3}^{2-}$ ions were observed only at two sampling locations, namely Bhaisma and Lakhanpur. $\mathrm{SO}_{4}^{2-}$ and $\mathrm{Cl}^{-}$concentrations ranged from $0.80 \mathrm{mg} / \mathrm{L}$ to $104.60 \mathrm{mg} / \mathrm{L}$ (mean value $=14.78 \mathrm{mg} / \mathrm{L}$ and $\mathrm{SD}=18.90 \mathrm{mg} / \mathrm{L}$ ) and $7.10 \mathrm{mg} / \mathrm{L}$ to $223.70 \mathrm{mg} / \mathrm{L}$ (mean value $=36.35 \mathrm{mg} / \mathrm{L}$ and $\mathrm{SD}=36.78 \mathrm{mg} / \mathrm{L}$ ), respectively. The $\mathrm{F}^{-}$in sampling locations varied between $0 \mathrm{mg} / \mathrm{L}$ and $2.10 \mathrm{mg} / \mathrm{L}$ (mean value $=0.24 \mathrm{mg} / \mathrm{L}$ and $\mathrm{SD}=0.44 \mathrm{mg} / \mathrm{L}$ ). The permissible limits of $\mathrm{HCO}_{3}^{-}, \mathrm{CO}_{3}^{2-}, \mathrm{SO}_{4}^{2-}, \mathrm{Cl}^{-}$and $\mathrm{F}^{-}$concentration in irrigation water are $250 \mathrm{mg} / \mathrm{L}, 15 \mathrm{mg} / \mathrm{L}, 180 \mathrm{mg} / \mathrm{L}, 250 \mathrm{mg} / \mathrm{L}$, and $10 \mathrm{mg} / \mathrm{L}$, respectively [32,33]. Based on these limits, all the locations had water suitable for irrigation use, except one location with regard to $\mathrm{HCO}_{3}{ }^{-}$concentration. Besides these, the other important anions analyzed were $\mathrm{SiO}_{2}$ and $\mathrm{PO}_{4}^{3-}$, their concentrations in groundwater samples varied from $3.30 \mathrm{mg} / \mathrm{L}$ to $118.70 \mathrm{mg} / \mathrm{L}$ (mean value $=33.61 \mathrm{mg} / \mathrm{L}$ and SD value $=26.80 \mathrm{mg} / \mathrm{L}$ ) and $0 \mathrm{mg} / \mathrm{L}$ to $2.41 \mathrm{mg} / \mathrm{L}$ (mean value $=0.36 \mathrm{mg} / \mathrm{L}$ and $S D$ value $=0.46 \mathrm{mg} / \mathrm{L}$ ), respectively.

\subsection{Groundwater chemistry based on interaction among ions}

Additionally, Na\%, SAR, RSC, PI, KR, and MAR were determined to assess the ionic hazards of the groundwater sample and to formulate grading standards of groundwater suitability for irrigation use in the study area.

$\mathrm{Na}^{+}$content has the ability for cation exchange reactions with calcium and magnesium ions, thereby making the soil structure impervious. These cationic exchange reactions may also result in deficiency of essential nutrient ions (calcium and magnesium) to the plants. Thus, the presence of excess sodium in water reduces permeability, thereby reducing water availability to plants for their growth. Na content (\%) in groundwater samples varied from 13.82 to $74.69 \%$ (mean value $=34.65 \%$ and $\mathrm{SD}=12.31 \%$ ) (Table 1 ). Based on sodium percentage values [34], irrigation water in the study area was categorized into four subclasses, i.e., $10.3 \%$ of samples had excellent water quality (0-20\%), $60.71 \%$ had good quality (20-40\%), $26.79 \%$ fell within the permissible range for irrigation use (40-60\%), and $1.79 \%$ came under the doubtful category (60-80\%) (Table 2). Khodapanah [35] reported that water with more than $60 \%$ of $\mathrm{Na}$ may cause accumulation of $\mathrm{Na}^{+}$ resulting in the breakdown of the physical properties of soils. Wilcox diagram plotted between EC as abscissa and $\mathrm{Na}$ as the ordinate showed that $98.21 \%$ of groundwater samples (55) fell within the excellent to good category and $1.79 \%$ (1) fell within the good to permissible category (Fig. 3). Hence with respect to Na percentage, the Wilcox plot confirms that the groundwater samples are suitable for irrigation usage.

SAR assesses sodic hazard to crops and water suitability for irrigation use [36]. High SAR values in irrigation water may need soil amendments to prevent long term damage to the soil as $\mathrm{Na}^{+}$concentration in water can displace the $\mathrm{Ca}^{2+}$ and $\mathrm{Mg}^{2+}$ ions in the soil. SAR values ranged from 0.17 to 2.46 (mean value $=0.88$ and $S D=0.61$ ) in the entire study area indicating all the samples were of excellent quality and suitable for irrigation (Table 2). For more details and accurate analysis, US Salinity Laboratory's (USSL) diagram [5] (Fig. 4) was plotted between EC representing salinity hazard as abscissa and SAR posing alkali hazard as ordinate to help define the extent of salinity/alkalinity effect on crops. Higher EC concentrations in water lead to saline soil whereas high $\mathrm{Na}^{+}$levels lead to formation of alkaline soil. Salinity hazard was categorized as $C_{1}=$ low salinity, $C_{2}=$ medium salinity, $C_{3}=$ high salinity,

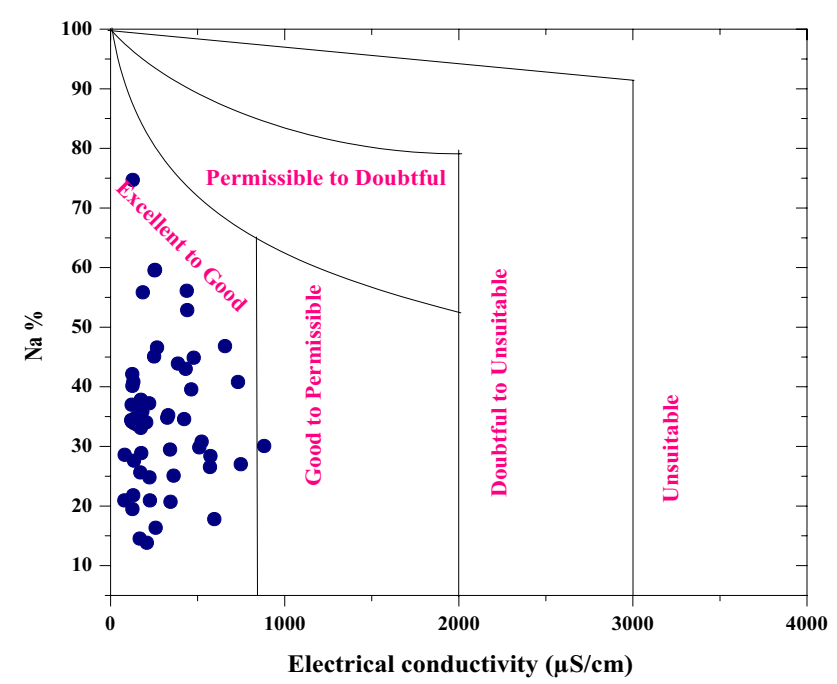

Fig. 3 Wilcox diagram showing the suitability of groundwater for irrigation 


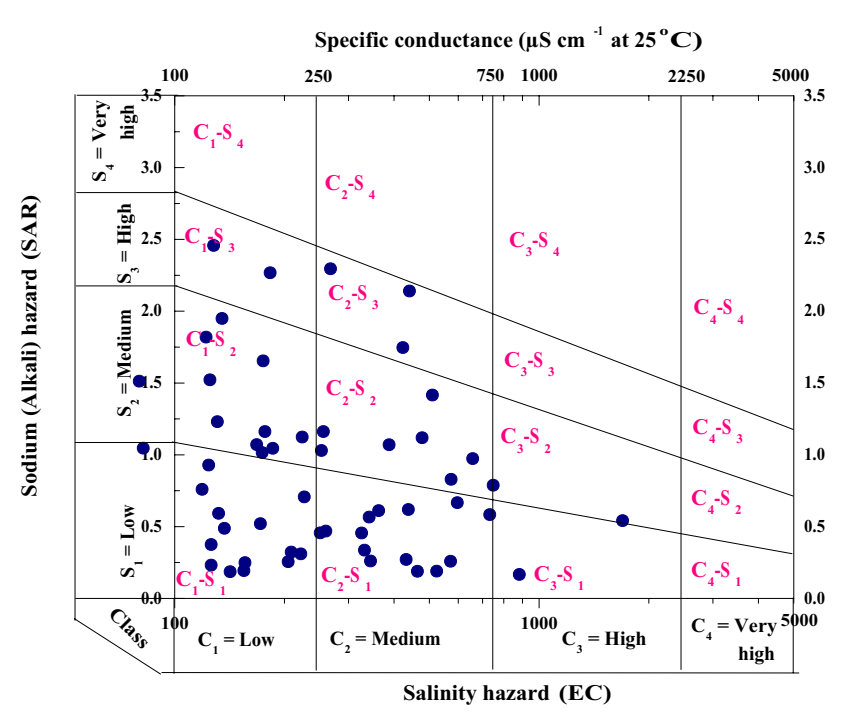

Fig. 4 USSL diagram for classifying irrigation waters on the basis of SAR and EC

and $\mathrm{C}_{4}=$ very high salinity and alkali hazard as $\mathrm{S}_{1}=$ low alkalinity, $\mathrm{S}_{2}=$ medium alkalinity, $\mathrm{S}_{3}=$ high alkalinity, and $\mathrm{S}_{4}=$ very high alkalinity. Around $27 \%$ of the samples fell in the $\mathrm{C}_{1}-\mathrm{S}_{1}$ zone and $27 \%$ under $\mathrm{C}_{2}-\mathrm{S}_{1}$, indicating lowmedium salinity with low alkali hazard. Only one sample fell in the $\mathrm{C}_{3}-\mathrm{S}_{1}$ zone, indicating high salinity and low alkali hazard. Hence, groundwater falling within the $C_{1}-S_{1}$ and $\mathrm{C}_{2}-\mathrm{S}_{1}$ zones can be used to irrigate all kinds of soils with the slight risk of increased levels of exchangeable $\mathrm{Na}^{+}$[37], while those in the $\mathrm{C}_{3}-\mathrm{S}_{1}$ zone can only be used to irrigate certain semi-tolerant crops [38]. Around $18 \%$ of the samples fell within the $\mathrm{C}_{1}-\mathrm{S}_{2}$ zone (low salinity-medium alkali hazard), $14 \%$ fell in the $C_{2}-S_{2}$ zone while only $4 \%$ fell within the $\mathrm{C}_{3}-\mathrm{S}_{2}$ zone, indicating medium to high salinity with medium alkali hazard. Groundwater in these areas can be used for irrigation when moderate amount of leaching takes place. However, continuous use of groundwater that falls under the $\mathrm{C}_{3}-\mathrm{S}_{2}$ zone can in the long run lead to both elevated salinity and alkalinity hazards in the soil. Around $10 \%$ of the samples fell under the $C_{1}-S_{3}$ and $C_{2}-S_{3}$ zones. The USSL plot thus indicated that the groundwater samples were suitable for irrigation.

When groundwater containing excessive $\mathrm{HCO}_{3}{ }^{-}$and $\mathrm{CO}_{3}^{2-}$ ions react with $\mathrm{Ca}^{2+}$ and $\mathrm{Mg}^{2+}$ ions, it causes precipitation of respective cations and forms calcite and magnesite that make the soil solution more concentrated, leading to increased $\mathrm{Na}^{+}$concentration in water due to the formation of $\mathrm{NaHCO}_{3}$ and $\mathrm{Na}_{2} \mathrm{CO}_{3}[6,39]$. The presence of excess anions $\left(\mathrm{HCO}_{3}{ }^{-}\right.$and $\left.\mathrm{CO}_{3}^{2-}\right)$ is denoted by
RSC, which in turn necessitates its evaluation with regard to irrigation suitability. Higher RSC in water reduces soil infiltration capacity, soil aeration, increases $\mathrm{pH}$, and inhibits root penetration, etc. [40,41]. From Table 1, it can be observed that groundwater samples in the study area showed RSC values ranging from -10.29 to 0.81 (mean value $=-0.51 \mathrm{meq} / \mathrm{L}$ and $S D=1.53 \mathrm{meq} / \mathrm{L}$ ), indicating all the sampling locations to be safe (Table 2) for irrigation use. While a negative RSC value denotes excess $\mathrm{Ca}^{2+}$ and $\mathrm{Mg}^{2+}$ concentration, a positive RSC denotes possible $\mathrm{Na}^{+}$presence in the soil. RSC is also important in calculating the amount of gypsum or sulphuric acid required per acre/foot in irrigation water to neutralize residual carbonate effect.

Soil permeability is affected in the long run because of irrigated water, which in turn reduces crop yield, necessitating the assessment of water suitability for irrigation based on the PI. PI is an essential parameter to evaluate bicarbonate and carbonate hazards in groundwater. Based on Doneen's classification, groundwater with $>75 \%$ PI comes under Class I, indicating excellent water for irrigation use. PI values between 25 and $75 \%$ are grouped under Class II indicating good water for irrigation use while $\mathrm{PI}<25 \%$ come under Class III, indicating water unsuitable for irrigation. PI values of the samples in the study area varied between 27.60 and $129.24 \%$ (mean value $=81.50 \%$ and $S D=19.84 \%$ ), as shown in Table 1. From Table 2, based on PI values it can be inferred that $66 \%$ of the samples belonged to Class I and $34 \%$ to Class II, which demonstrated that all groundwater sampling locations were suitable for irrigation use.

Kelly [16] determined the hazardous effect of $\mathrm{Na}^{+}$in groundwater for irrigation in terms of Kelly's ratio. It is computed based on the presence of $\mathrm{Na}^{+}, \mathrm{Ca}^{2+}$, and $\mathrm{Mg}^{2+}$ ions in the water. Kelly's ratio exceeding $1(K R>1)$ signifies elevated $\mathrm{Na}^{+}$level in water and that it is unsuitable for irrigation use, while $K R<1$ exhibits suitable quality water for irrigation. The $K R$ values of groundwater varied between 0.10 and 2.77 (mean value $=0.48$ and $S D=0.43$ ) within the study area (Table 1 ). The analysis (Table 2 ) showed that overall only 5 locations (9\%) had water with $K R>1$, indicating unfit water quality, whereas the rest of the locations (91\%) have $K R<1$ indicating good quality of water for irrigation.

Szaboles and Darab [42] proposed MAR to evaluate magnesium hazard in groundwater for irrigation purposes. In general, both $\mathrm{Ca}^{2+}$ and $\mathrm{Mg}^{2+}$ ions in water sustain an equilibrium condition. But the presence of excess $\mathrm{Mg}^{2+}$ ions in irrigation water changes soil quality, thereby reducing crop yields. It also damages the soil 
structure when water has high salinity and $\mathrm{Na}^{+}$content. Gupta and Gupta [43] reported that water with MAR value higher than $50 \%$ leads to the formation of alkaline soil, which in turn adversely affects crop yield. The MAR value of the samples in entire study area ranged from 9.90 to $62.24 \%$ (mean value $=35.92 \%$ and $S D=12.11 \%$ ) (Table 1). In this study, $9 \%$ of the total samples were found to having MAR value exceeding $50 \%$, rendering the water samples unsuitable for irrigation while majority of the total samples $(91 \%)$ are within limits $(<50 \%)$ and are considered suitable for irrigation purpose.

\subsection{Mechanism controlling hydrogeochemistry}

The Gibbs ratio for cations $\mathrm{Na}+\mathrm{K} /(\mathrm{Na}+\mathrm{K}+\mathrm{Ca})$ and anions $\mathrm{Cl} /\left(\mathrm{Cl}+\mathrm{HCO}_{3}\right)$ were plotted separately on $\mathrm{X}$-axis and respective TDS concentration ( $\mathrm{mg} / \mathrm{L}$ ) on Y-axis. The Gibbs ratio for cations (Fig. 5a) varied between 0.23 and 0.80 (mean value $=0.47$ ) and for anions (Fig. $5 b$ ) between 0.10 and 0.85 (mean value $=0.38$ ). From the plots (Figs. $5 a, b$ ), it can be inferred that the groundwater samples in the region fell in the rock dominance field, indicating the influence of rocks on groundwater in the aquifers.

The Piper plot (Fig. 6) demonstrated that the groundwater samples fell in the field of $\mathrm{Ca}-\mathrm{HCO}_{3}$ type (64\%), $\mathrm{Ca}-\mathrm{Mg}-\mathrm{Cl}$ type $(25 \%), \mathrm{Na}-\mathrm{Cl}$ type $(5 \%), \mathrm{Ca}-\mathrm{Na}-\mathrm{HCO}_{3}$ type (4\%), and $\mathrm{Ca}-\mathrm{Cl}$ type (2\%). The results reveal that groundwater is significantly dominated by $\mathrm{Ca}-\mathrm{HCO}_{3}$ type which may be due to rock-water interactions and associated dissolution of carbonates in the aquifer system. The prevailing of groundwater $\mathrm{Ca}-\mathrm{HCO}_{3}$ type in the aquifer system mainly due to the dissolution of calcite $\left(\mathrm{CaCO}_{3}\right)$

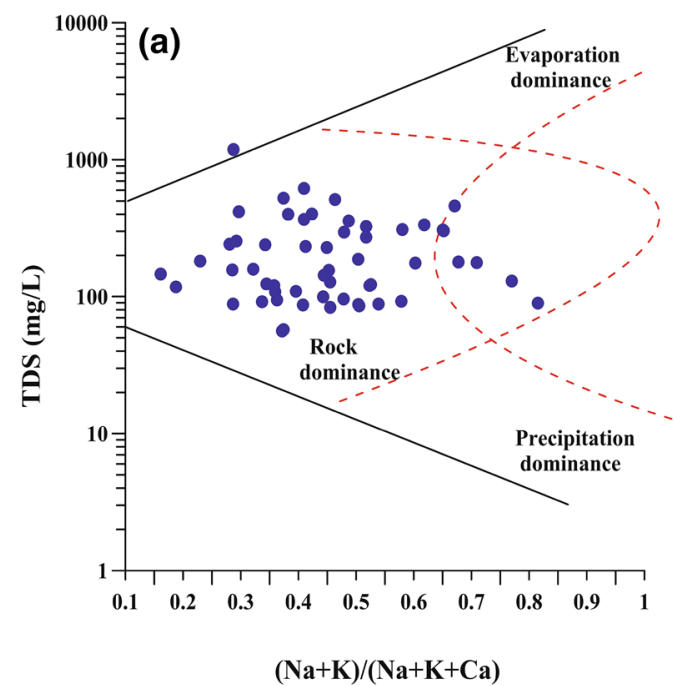

and dolomite $\left(\mathrm{CaMg}\left(\mathrm{CO}_{3}\right)\right.$ minerals present in bedrocks and soils which are described in Eqs. 8 and 9, respectively.

$\mathrm{CaCO}_{3}+\mathrm{H}^{+} \rightleftarrows \mathrm{HCO}_{3}+\mathrm{Ca}$

$\mathrm{CaMg}\left(\mathrm{CO}_{3}\right)+\mathrm{H}^{+} \rightleftarrows \mathrm{HCO}_{3}+\mathrm{Ca}+\mathrm{Mg}$

It can be inferred from Chadha's plot (Fig. 7) that $66 \%$ of the samples fell in the field of $\mathrm{Ca}-\mathrm{Mg}-\mathrm{HCO}_{3}$ type followed by $\mathrm{Ca}-\mathrm{Mg}-\mathrm{Cl} / \mathrm{SO}_{4}$ type (25\%), $\mathrm{Na}-\mathrm{Cl}$ type (5\%), and $\mathrm{Na}-\mathrm{HCO}_{3}$ type (4\%). Overall, results revealed that the alkaline earth $\left(\mathrm{Ca}^{2+}\right.$ and $\left.\mathrm{Mg}^{2+}\right)$ type water was dominant over alkalis $\left(\mathrm{Na}^{+}\right.$and $\mathrm{K}^{+}$), and the anionic weak acids $\left(\mathrm{HCO}_{3}{ }^{-}\right.$and $\left.\mathrm{CO}_{3}^{2-}\right)$ were predominant over anionic strong acids $\left(\mathrm{Cl}^{-}\right.$and $\left.\mathrm{SO}_{4}^{2-}\right)$. The $\mathrm{Ca}-\mathrm{Mg}-\mathrm{HCO}_{3}$ type was the dominant hydrogeochemical facies in the groundwater which was responsible for its temporary hardness, whereas the permanent hardness and lack of residual sodium carbonate in irrigation water were mainly due to $\mathrm{Ca}-\mathrm{Mg}-\mathrm{Cl} / \mathrm{SO}_{4}$ type of groundwater in the study region.

The Chloro Alkaline Indices values ranged between -3.39 and 0.59 (mean value $=-0.36$ and $S D=0.86$ ). The calculated CAI values of groundwater cations and anions showed both positive and negative values. A total of $60.71 \%$ (34 samples) of negative CAl values indicated the possible reverse ion exchange process and $39.29 \%$ (22 samples) of positive values (Fig. 8), inferred the direct base-exchange reaction of groundwater with $\mathrm{Na}^{+}$and $\mathrm{K}^{+}$with $\mathrm{Ca}^{2+}$ and $\mathrm{Mg}^{2+}$ of aquifer material. In the surrounding groundwater environment, where the dissolution of calcite, gypsum, and dolomite are dominant, the relation was observed in the vicinity of 1:1 between $\mathrm{Ca}^{2+}+\mathrm{Mg}^{2+}$ and $\mathrm{HCO}_{3}{ }^{-}+\mathrm{SO}_{4}^{2-}$ ions [44]. Abundance of

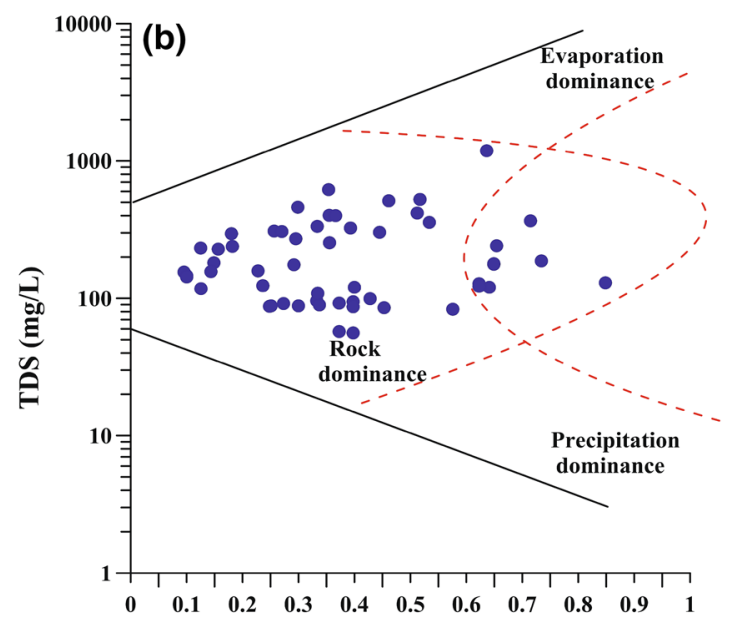

$\mathrm{Cl} /\left(\mathrm{Cl}+\mathrm{HCO}_{3}\right)$

Fig. 5 Gibbs plots (a) cations (b) anions 


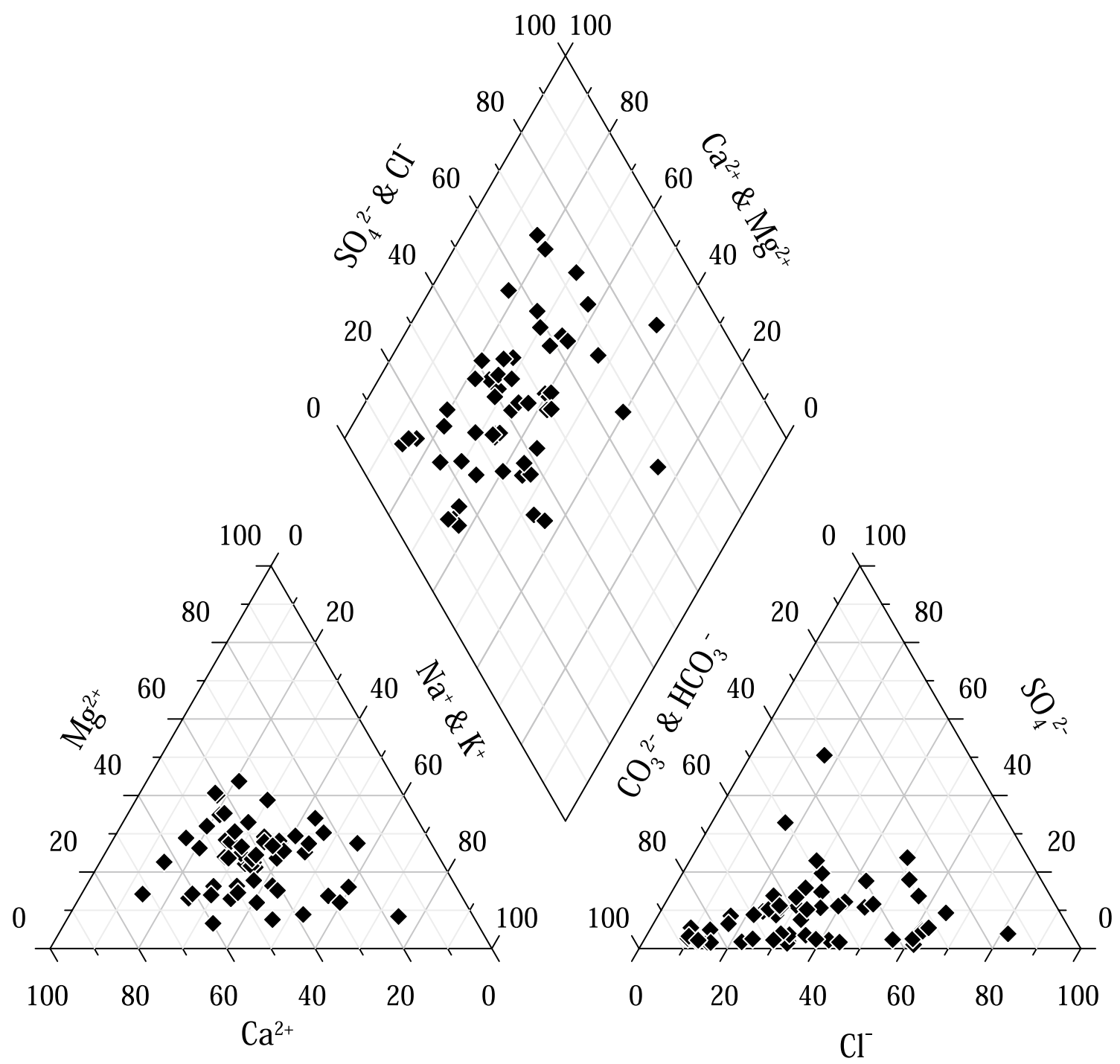

Fig. 6 Piper trilinear diagram of the study area

$\mathrm{Ca}^{2+}$ and $\mathrm{Mg}^{2+}$ ions in the ground water environment are mainly due to the cation-anion exchange process which shift the points to the left, while due to the process of direct ion exchange, the availabile anions $\left(\mathrm{HCO}_{3}^{-}+\mathrm{SO}_{4}^{2-}\right)$ dominate over $\mathrm{Ca}^{2+}+\mathrm{Mg}^{2+}$ and the points are shifted to the right [45]. Figure 9 showed that in 17 locations (30.36\%) groundwater samples lay below the 1:1 line while the samples in 39 locations (69.64\%) fell above the 1:1 line, indicating the dominance of reverse ion exchange process.

\section{Concluding remarks}

This study examined the suitability of groundwater for irrigation use and groundwater hydrogeochemistry in 56 groundwater samples in Korba district. The Na\%, SAR, RSC,
$\mathrm{PI}, \mathrm{KR}$, and MAR irrigation water quality indices were determined. Except the KR and MAR, the other indices revealed groundwater to be suitable for irrigation purposes. The physico-chemical analysis showed the predominance of the alkaline nature of groundwater within the study region. The dominant soluble cations observed were in the following order: $\mathrm{Ca}^{2+}>\mathrm{Mg}^{2+}>\mathrm{Na}^{+}>\mathrm{K}^{+}$and anions as $\mathrm{HCO}_{3}{ }^{-}>\mathrm{Cl}^{-}>\mathrm{SO}_{4}{ }^{2-}$. Results of the hydrogeochemical model suggested that the influence of rock-water interaction phenomena prevailed in the groundwater and the reverse ion exchange between alkalies in the groundwater and earth metal of the aquifer materials were the governing factors which regulates the groundwater chemistry. Groundwater hydrogeochemical facies observed through Piper plot followed by Chadha's diagram highlights that $\mathrm{Ca}-\mathrm{Mg}-\mathrm{HCO}_{3}$ type water dominates the groundwater. Overall, results 


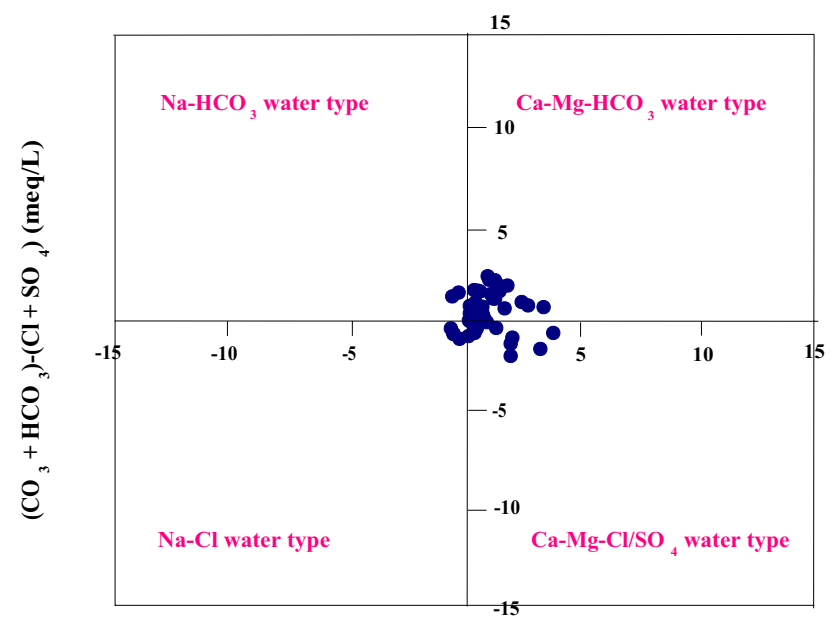

$(\mathrm{Ca}+\mathrm{Mg})-(\mathrm{Na}+\mathrm{K})(\mathbf{m e q} / \mathrm{L})$

Fig. 7 Classification of groundwater samples according to Chadha's plot

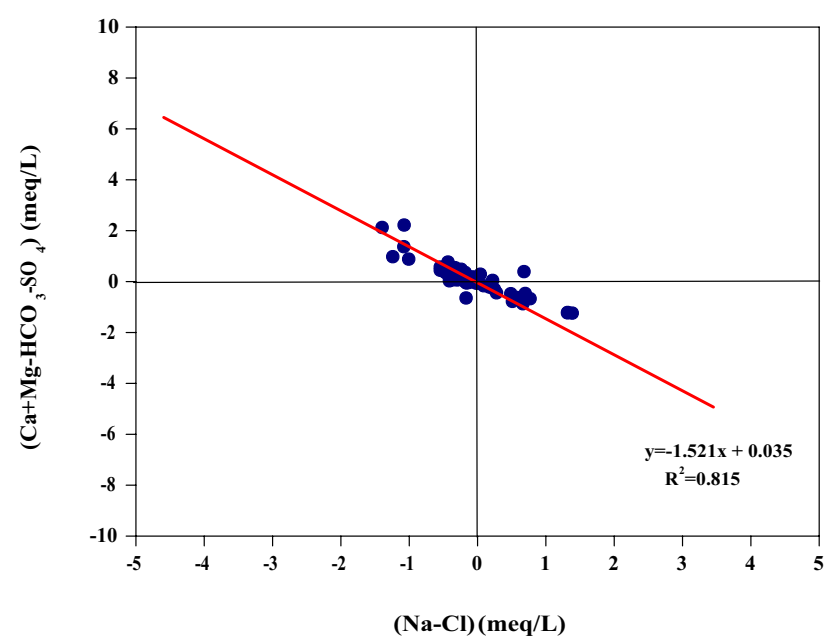

Fig. 8 Scatter plot of CAI

revealed that the existing groundwater was mostly suitable for irrigation purposes in the study area.

Future studies can be focused considering various hydrogeometeriological dataset to establish a groundwater quality prediction model. In addition inclusion of seasonal groundwater physico-chemical data can be used for the model validation purpose to chechk model performance and reliability.

Acknowledgements Authors would like to sincerely thank the Editor and the anonymous reviewers for providing their insightful suggestions for improving the quality of the manuscript. We acknowledge the support received from the authorities of IIT (ISM), Dhanbad for the current research work. Authors sincerely acknowledge the help received from Central Ground Water Board (CGWB), Raipur and for providing the necessary data and information utilized in the present work.

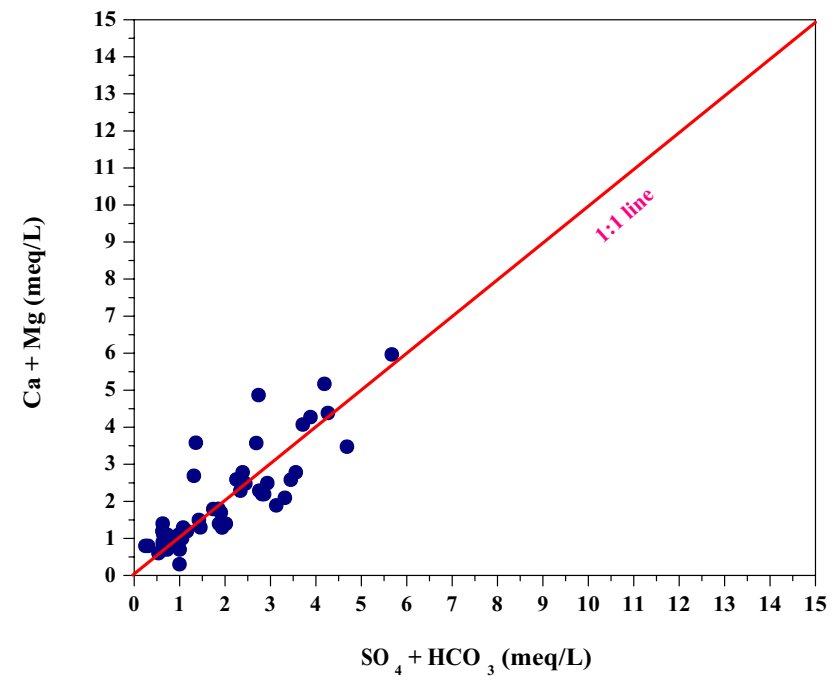

Fig. 9 Showing cross plots between $\left(\mathrm{Ca}^{2+}+\mathrm{Mg}^{2+}\right)$ and $\left(\mathrm{SO}_{4}^{2-}+\mathrm{HCO}_{3}^{-}\right)$

\section{Compliance with ethical standards}

Conflict of interest The authors declare that they have no conflict of interest.

\section{References}

1. Romanelli A, Lima ML, Londono OM, Martínez DE, Massone HE (2012) A GIS-based assessment of groundwater suitability for irrigation purposes in flat areas of the Wet Pampa Plain, Argentina. Environ Manag 50(3):490-503. https://doi.org/10.1007/ s00267-0129891-9

2. Varol S, Davraz A (2015) Evaluation of the groundwater quality with WQI (Water Quality Index) and multivariate analysis: a case study of the Tefenni plain (Burdur/Turkey). Environ Earth Sci 73(4):1725-1744. https://doi.org/10.1007/s12665-014-3531-z

3. Singha S, Pasupuleti S, Singha S, Villuri VGK (2017) An integrated approach for evaluation of groundwater quality in Korba district, Chhattisgarh using Geomatic techniques. J Environ Biol 38(5):865. https://doi.org/10.22438/jeb/38/5/MRN-600

4. Singh S, Ghosh NC, Gurjar S, Krishan G, Kumar S, Berwal P (2018) Index-based assessment of suitability of water quality for irrigation purpose under Indian conditions. Environ Monit Assess 190(1):29. https://doi.org/10.1007/s10661-017-6407-3

5. Richards LA (1954) Diagnosis and Improvement of Saline and Alkali Soil. Agricultural Handbook 60. United States Department of Agriculture, Washington, USA

6. Kabbilawsh P, Rajkumar R (2016) Incorporating factor analysis in GIS for assessment of groundwater quality for irrigation use. Int J Chem Sci 14(S1):31-50

7. Kurdi M, Tabasi S, Eslamkish T, Hezarkhani A (2013) Hydrogeochemical study to evaluate the suitability of water for irrigation purpose at Qareh sou catchment, North of Iran. Elixir Geosci 62:17536-17541

8. Little J, Kalischuk A, Gross D, Sheedy C (2010) Assessment of water quality in Alberta's irrigation districts. Alberta Agriculture and Rural Development, Alberta, p 181 
9. Arumugam K, Elangovan K (2009) Hydrochemical characteristics and groundwater quality assessment in Tirupur region, Coimbatore district, Tamil Nadu, India. Environ Geol 58(7):1509

10. Singha SS, Pasupuleti $S$, Singha $S$, Singh $R$, Venkatesh AS (2019) Analytic network process based approach for delineation of groundwater potential zones in Korba district, Central India using remote sensing and GIS. Geocarto Int. https://doi. org/10.1080/10106049.2019.1648566

11. CGWB (2013) Central Ground Water Board, Government of India. Ministry of Water Resources, Groundwater Brochure of Korba district, Chhattisgarh

12. Singha SS, Pasupuleti S, Singha S, Singh R, Venkatesh AS (2019) A GIS-based modified DRASTIC approach for geospatial modeling of groundwater vulnerability and pollution risk mapping in Korba district, Central India. Environ Earth Sci 78(21):628. https ://doi.org/10.1007/s12665-019-8640-2

13. Doneen LD (1964) Water quality for agriculture. Department of Irrigation, University of California, Davis, p 48

14. Wilcox LV (1955) Classification and use of Irrigation water. US Dept of Agriculture, Washington, Circular No. 969:19

15. Eaton FM (1950) Significance of carbonates in irrigated waters. Soil Sci 69:127-128

16. Kelly WP (1963) Use of saline irrigation water. Soil Sci 95(4):355-395

17. Paliwal KV (1972) Irrigation with saline water Monogram, vol 2. IARI, New Delhi, p 198

18. Rao NS, Rao PS, Reddy GV, Nagamani M, Vidyasagar G, Satyanarayana NL (2012) Chemical characteristics of groundwater and assessment of groundwater quality in Varaha River Basin, Visakhapatnam District, Andhra Pradesh, India. Environ Monit Assess 184(8):51895214. https://doi.org/10.1007/s10661-011-2333-y

19. Gibbs RJ (1970) Mechanisms controlling world water chemistry. Science 170(3962):1088-1090

20. Piper AM (1944) A graphic procedure in the geochemical interpretation of water-analyses. EOS Trans Am Geophys Union 25(6):914-928. https://doi.org/10.1029/TR025i006p00914

21. Chadha DK (1999) A proposed new diagram for geochemical classification of natural waters and interpretation of chemical data. Hydrogeol J 7(5):431-439. https://doi.org/10.1007/s100400050216

22. Subramani T, Rajmohan N, Elango L (2010) Groundwater geochemistry and identification of hydrogeochemical processes in a hard rock region, Southern India. Environ Monit Assess 162(1-4):123-137. https://doi.org/10.1007/s10661-009-0781-4

23. Sastri JCV (1994) Groundwater chemical quality in river basins, hydrogeochemical facies and hydrogeochemical modeling. Lecture notes-refresher course conducted by school of Earth Sciences. Bharathidasan University, Thiruchirapalli

24. Schoeller H (1977) Geochemistry of groundwater. In: Brown RH, Konoplyantsev AA, Ineson J, Kovalevsky VS (eds) Groundwater studies-an international guide for research and practice. pp 1-18

25. Ayers RS, Westcot DW (1985) Water quality for irrigation. FAO Irrig Drain Paper, 20

26. WHO (2004) Guidelines for Drinking-water Quality, 3rd edn. World Health Organization, Geneva

27. Tatawat RK, Chandel CS (2008) A hydrochemical profile for assessing the groundwater quality of Jaipur City. Environ Monit Assess 143(1-3):337-343. https://doi.org/10.1007/s1066 1-0079936-3

28. WHO (2008) Guidelines for drinking-water quality: incorporating first and second addenda, recommendations, vol 1, 3rd edn. WHO Press, france, $\mathrm{p} 668$

29. FAO (2006) Food and Agriculture Organization, Prospects for food, nutrition, agriculture, and major commodity groups. World agriculture: toward 2030-2050, Interim report. Global Perspective StudiesUnit. FAO, Rome
30. Sawyer C, McCarty P, Parkin G (2003) Chemistry for Environmental Engineering and Science. Mc GrawHill, New York

31. Van der Aa M (2003) Classification of mineral water types and comparison with drinking water standards. Environ Geol 44(5):554-563. https://doi.org/10.1007/s00254-003-0791-4

32. Sharifi Z, Safari Sinegani AA (2012) Arsenic and other irrigation water quality indicators of groundwater in an agricultural area of Qorveh Plain, Kurdistan, Iran. Am Eurasian J Agric Environ Sci 12(4):548-555

33. Nagaraju A, Kumar KS, Thejaswi A (2014) Assessment of groundwater quality for irrigation: a case study from Bandalamottu lead mining area, Guntur District, Andhra Pradesh, South India. Appl Water Sci 4(4):385-396. https://doi.org/10.1007/s1320 1-014-0154-1

34. Munna K, Guhey R, Jhariya DC (2019) Hydrogeochemistry of high fluoride groundwater to understand the suitability of groundwater for drinking and irrigation purposes in granulite belt part of Bhopalpatnam Area, Bijapur District, Chhattisgarh. India. J Geol Soc of India 94(3):309-318. https://doi.org/10.1007/ s12594-019-1311-9

35. Khodapanah LWNA, Sulaiman WNA, Khodapanah N (2009) Groundwater quality assessment for different purposes in Eshtehard District, Tehran, Iran. Eur J Sci Res 36(4):543-553

36. Khan R, Jhariya DC (2018) Hydrogeochemistry and Groundwater Quality Assessment for Drinking and Irrigation Purpose of Raipur City, Chhattisgarh. J Geol Soc India 91(4):475-482. https ://doi.org/10.1007/s12594-018-0881-2

37. Salifu M, Aidoo F, Hayford MS, Adomako D, Asare E (2017) Evaluating the suitability of groundwater for irrigational purposes in some selected districts of the Upper West region of Ghana. Appl Water Sci 7(2):653-662. https://doi.org/10.1007/s1320 1-015-0277-z

38. Ahamed AJ, Ananthakrishnan S, Loganathan K, Manikandan $\mathrm{K}$ (2013) Assessment of groundwater quality for irrigation use in Alathur block, Perambalur district, Tamilnadu, South India. Appl Water Sci 3(4):763-771. https://doi.org/10.1007/s1320 1-013-0124-z

39. Sadashivaiah CR, Ramakrishnaiah CR, Ranganna G (2008) Hydrochemical analysis and evaluation of groundwater quality in Tumkur Taluk, Karnataka State, India. Int J Environ Res Public Health 5(3):158-164

40. Todd DK, Mays LW (2005) Groundwater hydrology edition. Welly Inte

41. Das S, Nag SK (2015) Deciphering groundwater quality for irrigation and domestic purposes-a case study in Suri I and II blocks, Birbhum District, West Bengal, India. J Earth Syst Sci 124(5):965992. https://doi.org/10.1007/s12040-015-0583-8

42. Szaboles I, Darab C (1964) The influence of irrigation water of high sodium carbonate content of soils. In: Proceedings of $8^{\text {th }}$ international congress of ISSS, Trans, II, pp 803-812

43. Gupta SK, Gupta IC (1987) Management of Saline Soils and Water. Oxford and IBH publication Co., New Delhi, p 399

44. Sonkamble S, Sahya A, Mondal NC, Harikumar P (2012) Appraisal and evolution of hydrochemical processes from proximity basalt and granite areas of Deccan Volcanic Province (DVP) in India. J Hydrol 438:181-193

45. Cerling TE, Pederson BL, Von Damm KL (1989) Sodium-calcium ion exchange in the weathering of shales: implications for global weathering budgets. Geology 17(6):552-554. https://doi. org/10.1130/0091-7613(1989)017\%3c0552:SCIEIT\%3e2.3.CO;2

Publisher's Note Springer Nature remains neutral with regard to jurisdictional claims in published maps and institutional affiliations. 